\title{
Gall bladder emptying patterns in response to a normal meal in healthy subjects and patients with gall stones: ultrasound study
}

\author{
P J Howard, G M Murphy, R H Dowling
}

\begin{abstract}
In this study gall bladder emptying patterns in response to a solid meal were studied using ultrasound. A similar triphasic pattern was seen in eight healthy control subjects and eight patients with gall stones, with 'early' and 'late' net emptying phases separated by a period of net refilling with peak postprandial gall bladder volumes occurring at (mean (SD)) 33.1 (17.9) minutes and $27.4(18.8)$ minutes in control subjects and patients, respectively. A phase of slower net emptying followed, which was complete at 146 (33) minutes in control subjects and 125 (33) minutes in the gall stone patients (not significant). Superimposed upon this overall triphasic pattern, postprandial gall bladder emptying was punctuated by repeated short lived episodes of filling and emptying. The mean (SD) estimated postprandial bile outputs were $0.83(0.34) \mathrm{ml} / \mathrm{min}$ in four control subjects and $1.2(1 \cdot 1) \mathrm{ml} / \mathrm{min}$ in seven patients with gall stones. We propose a 'washout' model to reconcile this large turnover of bile with the concentrating and storage functions of the gall bladder and predict that the extent rather than the rate of gall bladder emptying is important in determining stasis of bile in the gall bladder.
\end{abstract}

Impaired gall bladder motility may be important in the pathogenesis of gall stones.' Thus abnormal gall bladder emptying has been implicated in gall stone formation during pregnancy, ${ }^{23}$ in patients taking female sex hormones ${ }^{34}$ and in those on longterm parenteral nutrition. ${ }^{56}$ Furthermore, in the prairie dog in vitro gall bladder muscle contractility and in vivo gall bladder emptying, measured cholescintigraphically, are impaired before and during gall stone formation..$^{7-9}$ Previous studies, however, of gall bladder dynamics in patients with gall stones have yielded conflicting results. Enhanced, ${ }^{10}$ normal, ${ }^{11}$ or impaired gall bladder emptying ${ }^{11-15}$ have all been described. In theory these conflicting conclusions may be due either to variations in gall bladder emptying after oral or intravenous stimuli or to differences in methodology, or both. Several parameters have been used to measure gall bladder emptying including the difference between initial and final volumes (the 'delta volume'), the ejection fraction, the emptying rate constant $(k)$ and the $t^{1 / 2}$ of emptying. They all assume that the gall bladder empties in a steady progressive fashion. This assumption has been challenged by Jazrawi et al, ${ }^{16}$ who used a dual isotope technique, and by our own preliminary ultrasound studies of gall bladder motility. ${ }^{17}$ The results of these two studies show that the gall bladder undergoes repeated episodes of filling and emptying over short periods of time, both in the fasting state and in response to meals. Jazrawi and coworkers have since confirmed their initial observations by quantifying absolute gall bladder filling and emptying in gall stone patients using the combination of duodenal perfusion and isotope techniques, with two separate markers to label gall bladder bile and hepatic bile. ${ }^{18}$

If meal stimulated gall bladder emptying under physiological conditions is indeed complex, and punctuated by repeated episodes of refilling, the actual volume of bile handled by the gall bladder will have been underestimated in previous studies. The aim of this study, therefore, was to examine gall bladder emptying in response to a normal meal in healthy control subjects and patients with gall stones, using ultrasound.

\section{Methods}

SUBJECTS

Gall bladder emptying was studied in eight patients with gall stones (one man and seven women) with a mean (SD) age of 54 (13.6) years and in eight healthy men with a mean (SD) age of $32(6 \cdot 7)$ years. None was taking regular medication, although one patient occasionally took antacids for heartburn. All premenopausal patients were studied during the first 10 days of the menstrual cycle. ${ }^{3}$

\section{ESTIMATION OF GALL BLADDER VOLUME BY} ULTRASOUND

Images of the gall bladder were obtained using a real time ultrasound system with a $128 \mathrm{~mm}$ 3.0 MHz 'linear array' transducer (System 285, Diagnostic Sonar, Livingston, Scotland). At the end of inspiration the gall bladder was scanned along its long axis, the resultant image 'frozen' on the oscilloscope screen and traced onto a cellophane sheet. Gall bladder volume was estimated from the silhouette using the sum of cylinders method described by Everson et al ${ }^{19}$ and a commercial plotter (Datacorp Type 4 Datalizer, GTCO, Rockville, Maryland) connected to an Apple II computer.

VALIDATION OF METHOD USED TO ESTIMATE

CHANGES IN GALL BLADDER VOLUME

To confirm that the observed changes in gall bladder volume were real and not artefactual, the 
magnitude of the minute-by-minute fluctuations in gall bladder length and width were measured for 20 minutes before, and for 20 minutes after, a continuous 20 minute infusion of 100 Ivy dog units of cholecystokinin (Pancreozymin, Boots, Nottingham). Since cholecystokinin induces gall bladder contraction it would be expected to decrease the minute-by-minute fluctuations in the length and width of the gall bladder. Therefore, any increase in these minute-by-minute flunctuations would indicate that the changes were due to alterations in the dimensions of the gall bladder itself rather than to artefact.

Table I gives the results of minute-by-minute estimations of maximum gall bladder length and width before and after cholecystokinin in two control subjects. In the first, overall gall bladder length and width both decreased after cholecystokinin. But there were minute-by-minute fluctuations in the length and width of the gall bladder, and the amplitude of these fluctuations increased after the gall bladder had contracted in response to cholecystokinin. The mean (SEM) minute-by-minute fluctuations in width increased from $1 \cdot 12(0 \cdot 16) \mathrm{mm}$ to $2 \cdot 11(0 \cdot 36) \mathrm{mm}$ $(\mathrm{p}<0.025)$ and in length from $1.81(0.34)$ to 2.91 $(0.52) \mathrm{mm}(\mathrm{p}<0.05)$. In the second subject there were again significant falls in overall gall bladder length and width in response to cholecystokinin But the minute-by-minute fluctuations in length increased from $1.66(0.21) \mathrm{mm}$ to $6.20(0.91) \mathrm{mm}$ $(\mathrm{p}<0.01)$. The fluctuations in measurements of width also increased, but the increase was not significant.

\section{ESTIMATION OF OBSERVER ACCURACY IN DETERMINING GALL BLADDER SIZE}

The fact that the volume of a cylinder is proportional to its length and to the square of its diameter was used to estimate the experimental error in estimating gall bladder volume in vivo. For 'large' gall bladders a given change in diameter would have proportionally greater effects on the calculated volume than the same change in length. Therefore, if the gall bladder is regarded as a cylinder of constant length, the magnitude of the changes in volume can be calculated. The error in measuring gall bladder volume was estimated by making repeated volume measurements of two large 'static' fasting gall bladders over 10 minutes. The changes in diameter of a cylinder of the same mean

TABLE I Mean (SEM) minute-by-minute fluctuations in gall bladder length and width in two healthy subjects before and after cholecystokinin infusions

\begin{tabular}{|c|c|c|c|c|}
\hline & \multicolumn{4}{|c|}{ Gall bladder } \\
\hline & $\begin{array}{l}\text { Mean } \\
\text { length } \\
(\mathrm{mm})\end{array}$ & $\begin{array}{l}\text { Mean } \\
\text { width } \\
(\mathrm{mm})\end{array}$ & $\begin{array}{l}\text { Mean fluctuation } \\
\text { in length } \\
(\mathrm{mm})\end{array}$ & $\begin{array}{l}\text { Mean fluctuation } \\
\text { in width } \\
\text { (mm) }\end{array}$ \\
\hline \multicolumn{5}{|l|}{ Subject 1: } \\
\hline Before cholecystokinin & $\begin{array}{c}37 \cdot 70 \\
(0 \cdot 37)\end{array}$ & $\begin{array}{l}28 \cdot 09 \\
(0 \cdot 27)\end{array}$ & $\begin{array}{c}1.81 \\
(0.34)\end{array}$ & $\begin{array}{c}1 \cdot 12 \\
(0.16)\end{array}$ \\
\hline After cholecystokinin & $\begin{array}{l}36 \cdot 08 \\
(0 \cdot 68)\end{array}$ & $\begin{array}{l}17 \cdot 55 \\
(0.57)\end{array}$ & $\begin{array}{c}2.91 \\
(0.52)\end{array}$ & $\begin{array}{l}2 \cdot 11 \\
(0.36)^{\star}\end{array}$ \\
\hline \multirow{2}{*}{$\begin{array}{l}\text { Subject } 2 \text { : } \\
\quad \text { Before cholecystokinin }\end{array}$} & & & & \\
\hline & $\begin{array}{c}61 \cdot 03 \\
(0.36)\end{array}$ & $\begin{array}{c}27 \cdot 32 \\
(0 \cdot 30)\end{array}$ & $\begin{array}{c}1 \cdot 66 \\
(0 \cdot 21)\end{array}$ & $\begin{array}{c}1.53 \\
(0.27)\end{array}$ \\
\hline After cholecystokinin & $\begin{array}{c}43.18 \\
(1.22)\end{array}$ & $\begin{array}{l}16.68 \\
(0.63)\end{array}$ & $\begin{array}{l}6.20 \\
(0.91) \dagger\end{array}$ & $\begin{array}{c}2 \cdot 12 \\
(0.29)\end{array}$ \\
\hline
\end{tabular}

${ }^{\star} \mathrm{p}<0.01 ; \mathrm{pp}<0.001$.
TABLE II Estimated minute-by-minute changes in volume in two large and apparently 'static' gall bladders in two patients with gall stones. The changes in diameter (delta diameters) of model cylinders of the same mean length and volume as the gall bladders that would be required to 'generate' the observed changes in gall bladder volume have been calculated

\begin{tabular}{|c|c|c|c|}
\hline \multirow{2}{*}{\multicolumn{2}{|c|}{$\begin{array}{l}\text { Mean gall bladder length }(\mathrm{mm}) \\
\text { Mean gall bladder volume }(\mathrm{ml}) \\
\text { Calculated diameter of model } \\
\text { cylinder of equivalent length } \\
\text { and volume }(\mathrm{mm})\end{array}$}} & \multirow{2}{*}{$\begin{array}{l}\text { Patient I } \\
81 \cdot 3 \\
47 \cdot 6\end{array}$} & \multirow{2}{*}{$\begin{array}{l}\text { Patient } 2 \\
57 \cdot 9 \\
46 \cdot 5\end{array}$} \\
\hline & & & \\
\hline \multicolumn{2}{|c|}{$\begin{array}{l}\text { Delta volumes (ml) } \\
\text { (actual gall bladder volume - } \\
\text { mean gall bladder volume) }\end{array}$} & \multicolumn{2}{|c|}{$\begin{array}{l}\text { Delta diameter ( } \mathrm{mm} \text { ) } \\
\text { (change in diameter of model } \\
\text { cylinder required to generate } \\
\text { delta volume) }\end{array}$} \\
\hline Patient 1 & Patient 2 & Patient 1 & Patient 2 \\
\hline $\begin{array}{l}+0.85 \\
-2.71 \\
-0.68 \\
+2.48 \\
+4.41 \\
-3.21 \\
-2.81 \\
-2.86 \\
+1.03 \\
+3.54 \\
\operatorname{Mean}(\mathrm{SD})\end{array}$ & $\begin{array}{l}-1.97 \\
-5 \cdot 17 \\
-4.05 \\
-4.00 \\
-2.64 \\
+1.31 \\
+0.62 \\
+5.79 \\
+4.24 \\
+5 \cdot 87\end{array}$ & $\begin{array}{c}0.19 \\
0.62 \\
0.15 \\
0.55 \\
0.98 \\
0.74 \\
0.64 \\
0.65 \\
0.23 \\
0.79 \\
0.55 \\
(0.28)\end{array}$ & $\begin{array}{c}0.54 \\
1.42 \\
1.11 \\
1.09 \\
0.72 \\
0.35 \\
0.17 \\
1.53 \\
1.12 \\
1.55 \\
0.96 \\
0.49\end{array}$ \\
\hline \multicolumn{2}{|c|}{ Overall mean $(\mathrm{SD})(\mathrm{mm})$} & \multicolumn{2}{|c|}{$\begin{array}{c}0.76 \\
(0.44)\end{array}$} \\
\hline
\end{tabular}

volume and length that would be required to 'generate' the observed gall bladder volume changes were than calculated.

Table II shows the results of minute-byminute observations in two patients with gall stones with large static gall bladders, each of whom was studied over a 10 minute period. Assuming that these large gall bladders were of constant volume throughout the 10 minutes of observation and equating them to cylinders of the same mean length and volume, the changes in diameter ('delta diameters') of the model cylinders required to produce the observed changes in gall bladder volume were calculated. In the first patient the mean (SD) change was $0.55(0.28) \mathrm{mm}$ and in the second 0.96 $(0.49) \mathrm{mm}$. Therefore, the overall mean (SD) of the individual delta diameters was 0.76 $(0.44) \mathrm{mm}$. This figure was taken as a measure of the observer accuracy in estimating gall bladder size.

\section{GALL BLADDER EMPTYING IN RESPONSE TO A} NORMAL MEAL

The control subjects and patients were studied after an overnight fast of not less than 12 hours. Table III gives the composition of the test meal. Scans were taken before the meal was eaten to estimate the 'fasting' gall bladder volume. It soon became apparent, however, that there was preingestion gall bladder evacuation and therefore, in order to determine the extent of this 'cephalic phase' emptying, serial measurements of gall bladder volume were made before the meal. The immediate preingestion gall bladder volume was taken as the 'fasting volume.' Time 0 was arbitrarily defined as the mid-point of meal ingestion. The control subjects and patients then lay semirecumbent throughout the study and frequent scans were taken for not less than two hours, or until there was net refilling of the gall 
TABLE III Composition of test meal

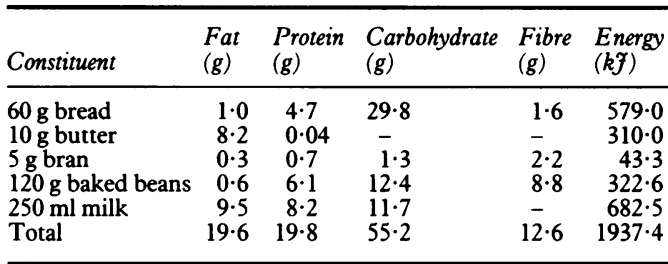

bladder. During the first two studies in control subjects scans were taken every 10 to 15 minutes. When it became clear that the gall bladder was undergoing rapid changes in volume, the sampling interval was reduced to five minutes or less. In four of the control subjects and in seven of the patients scans were performed at one minute intervals.

\section{Results}

\section{GROSS GALL BLADDER EMPTYING PATTERNS}

\section{Cephalic phase emptying}

In five of eight control subjects and in all eight patients with gall stones there was evidence of net gall bladder emptying before the start of the meal, but in the remaining three control subjects there was no such cephalic phase.

\section{Postprandial gall bladder emptying patterns}

The pattern of gall bladder emptying was triphasic, with early emptying, early refilling, and late emptying phases. This pattern was similar in control subjects and patients. Figure 1 shows an individual example, while Figure 2 shows the mean overall filling and emptying patterns in both groups.

Postprandial gall bladder emptying was complex and did not conform to a simple exponential pattern. In six out of eight control subjects and in all eight patients there was an early net emptying phase with a mean (SD) fall in gall bladder volume from $10 \cdot 7(4.8) \mathrm{ml}$ immediately before

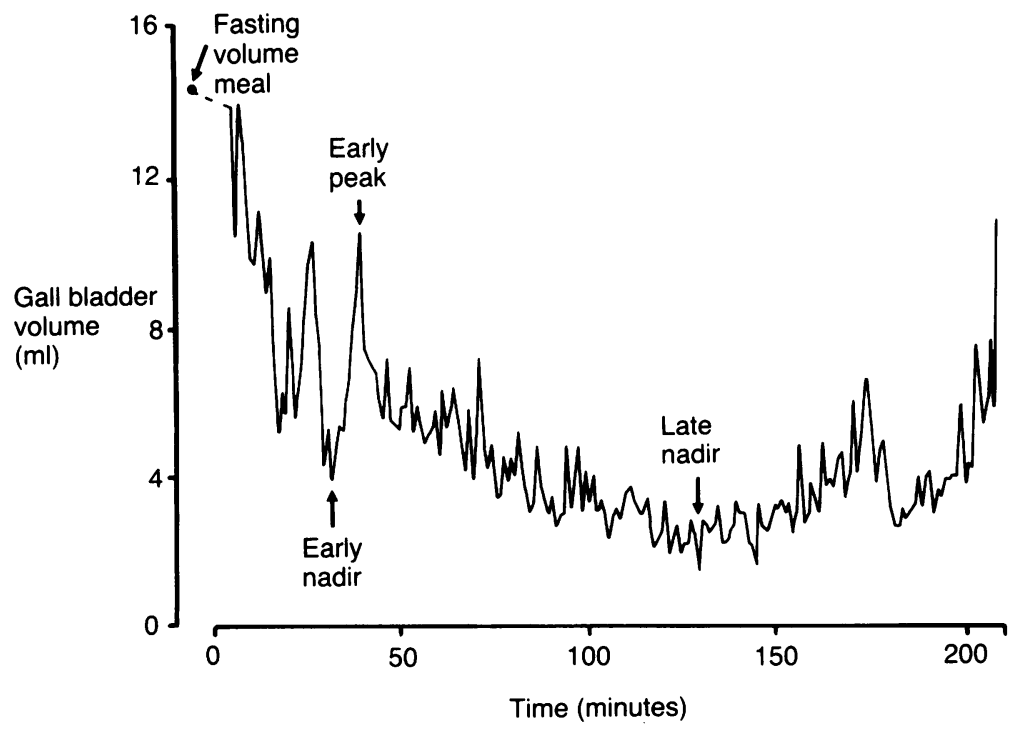

Figure 1: A representative example of a gall bladder emptying profile in a normal volunteer in which measurements of gall bladder volume were made at one minute intervals.
TABLE IV Estimated postprandial delta volumes, ejection fractions, total outputs, and mean minute outputs of bile in four control subjects and seven patients with gall stones from meal ingestion to the time of the late nadir volumes. The 'delta volume' is defined as the difference between the immediate preingestion or fasting gall bladder volume $(F V)$ and the 'late' nadir volume. The ejection fraction is the overall decrease in gall bladder volume expressed as a percentage of the fasting volume

\begin{tabular}{|c|c|c|c|c|}
\hline & $\begin{array}{l}\text { Delta } \\
\text { volume } \\
(\mathrm{ml})\end{array}$ & $\begin{array}{l}\text { Total } \\
\text { output } \\
\text { (ml) }\end{array}$ & $\begin{array}{l}\text { Ejection } \\
\text { fraction } \\
(\% F V)\end{array}$ & $\begin{array}{l}\text { Mean } \\
\text { output } \\
\text { (ml/min) }\end{array}$ \\
\hline \multicolumn{5}{|c|}{ Healthy control subjects: } \\
\hline 1 & $14 \cdot 3$ & $57 \cdot 5$ & $90 \cdot 9$ & 0.41 \\
\hline 2 & $11 \cdot 3$ & $89 \cdot 8$ & $70 \cdot 8$ & 0.75 \\
\hline 3 & 11.9 & 93.9 & $80 \cdot 8$ & 0.96 \\
\hline 6 & $4 \cdot 5$ & $156 \cdot 0$ & $44 \cdot 4$ & $1 \cdot 22$ \\
\hline Mean $(\mathrm{SD})$ & $10 \cdot 5$ & $86 \cdot 8$ & $71 \cdot 7$ & 0.83 \\
\hline & $(4 \cdot 2)$ & $(60 \cdot 9)$ & $(20 \cdot 0)$ & $(0 \cdot 34)$ \\
\hline \multicolumn{5}{|c|}{ Patients with gall stones: } \\
\hline 9 & $12 \cdot 2$ & $70 \cdot 6$ & $78 \cdot 4$ & 0.67 \\
\hline 10 & $15 \cdot 4$ & $74 \cdot 3$ & $89 \cdot 9$ & 0.75 \\
\hline 12 & $10 \cdot 2$ & $230 \cdot 3$ & $19 \cdot 9$ & $2 \cdot 07$ \\
\hline 13 & 6.8 & $382 \cdot 7$ & $13 \cdot 0$ & $1 \cdot 22$ \\
\hline 14 & $6 \cdot 5$ & $64 \cdot 3$ & $87 \cdot 9$ & $0 \cdot 38$ \\
\hline 15 & $14 \cdot 0$ & $145 \cdot 0$ & $63 \cdot 0$ & $1 \cdot 10$ \\
\hline \multirow{3}{*}{${ }^{16}$ Mean (SD) } & $2 \cdot 6$ & $44 \cdot 8$ & $65 \cdot 5$ & 0.40 \\
\hline & $9 \cdot 7$ & $144 \cdot 6$ & $59 \cdot 6$ & $1 \cdot 2$ \\
\hline & $(4 \cdot 6)$ & $(123 \cdot 0)$ & $(17 \cdot 8)$ & $(1 \cdot 1)$ \\
\hline
\end{tabular}

the meal to $7 \cdot 5(4 \cdot 4) \mathrm{ml}$ at $14 \cdot 1(7 \cdot 7)$ minutes in control subjects and from $22 \cdot 0(19 \cdot 4) \mathrm{ml}$ to $17 \cdot 3$ $(17 \cdot 2) \mathrm{ml}$ at $18 \cdot 5(12 \cdot 4)$ minutes in patients. This was followed by a period of early net refilling in all 16. As a result, the peak gall bladder volumes were $15 \cdot 1(9 \cdot 9) \mathrm{ml}$ at $33 \cdot 1(17 \cdot 9)$ minutes in the control subjects and $24 \cdot 9(23 \cdot 4) \mathrm{ml}$ at $27 \cdot 4(18 \cdot 8)$ minutes in the patients. After this net refilling there was a slower phase of net emptying during which gall bladder volume fell to reach a late nadir of $2.4(1.9) \mathrm{ml}$ at $146(33)$ minutes in control subjects and $13 \cdot 2(18 \cdot 8) \mathrm{ml}$ at $125(33)$ minutes in the patients.

Minute-by-minute gall bladder filling and emptying Superimposed on the overall triphasic pattern, postprandial gall bladder emptying was punctuated by repeated, short lived episodes of filling and emptying throughout in all 16 patients and subjects studied. Table IV gives the estimated total output from the time of eating the meal to the time of the late nadir in the 11 who were studied at one minute intervals. In the healthy subjects the mean total output was eight times greater than the average delta volume and in the patients it was about 15 times greater. The mean (SD) estimated bile outputs per minute were $0.83(0.34) \mathrm{ml} / \mathrm{min}$ and $1.2(1.1) \mathrm{ml} / \mathrm{min}$ in control subjects and patients respectively. There were no correlations between (i) delta volume and mean minute output $(\mathrm{r}=0 \cdot 012 ; \mathrm{n}=11)$, (ii) fasting volume and delta volume $(r=0 \cdot 10 ; n=$ 11), (iii) fasting volume and ejection fraction $(\mathrm{r}=-0 \cdot 19 ; \mathrm{n}=11)$, or (iv) mean minute output and ejection fraction $(r=-0.053 ; n=11)$. There was, however, a significant positive correlation between fasting volume and mean minute output $(\mathrm{r}=0.77 ; \mathrm{p}<0.01 ; \mathrm{n}=11)$.

Contour changes in the gall bladder during emptying and refilling

Figure 3 shows two sets of superimposed gall bladder silhouettes, one obtained from a healthy 


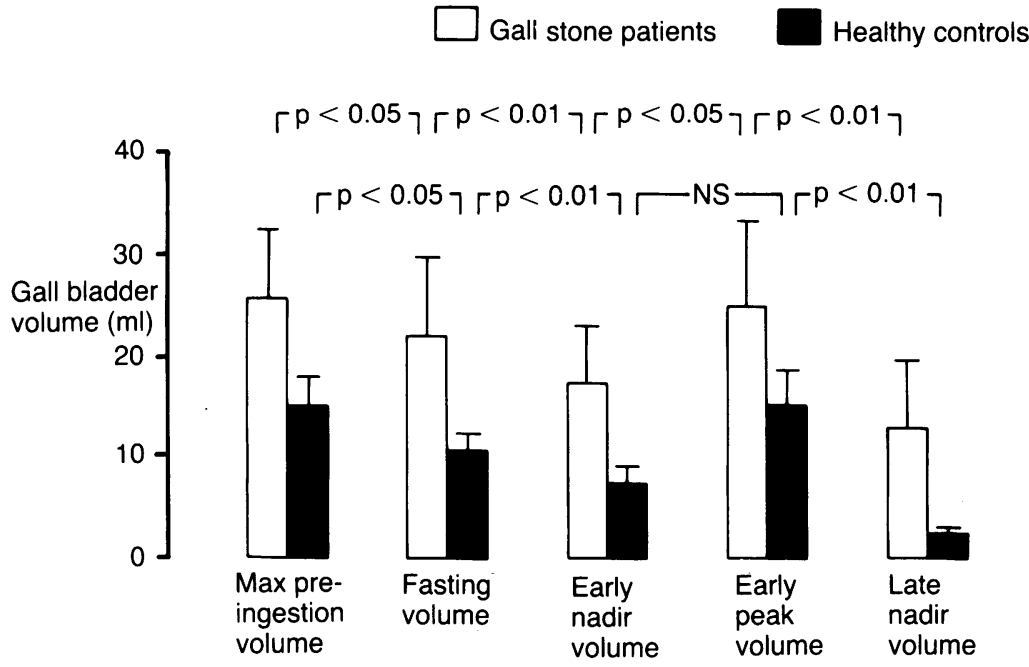

Figure 2: Overall filling and emptying patterns in patients with gall stones and control subjects. Means (SEM) are shown.

\section{Discussion}

The aim of this study was to examine the patterns of gall bladder emptying in healthy subjects and patients with gall stones in response to a solid meal. Ultrasound is safe, non-invasive, and allows repeated measurements of gall bladder volume at short time intervals. It also provides information about the gall bladder during filling and emptying. On the other hand, ultrasonography requires patient cooperation and observer skill to obtain satisfactory images which can only be recorded intermittently, rather than continuously. The calculation of gall bladder volume also depends on certain assumptions about gall bladder geometry.

For the present study it was therefore necessary to show that the observed changes in volume were due to changes in the gall bladder itself rather than to observer error or to measurement artefact. This was done in two ways. Firstly, we showed that the minute-by-minute fluctuations in the length and width of the gall bladder actually increased after gall bladder contraction had been induced by cholecystokinin. Secondly, we estimated the apparent 'error' in widthwise measurement from repeated measurements of large 'static' gall bladders. The estimated mean (SD) error in measuring the diameter of two large gall bladders was $0.76(0.44) \mathrm{mm}$. For any particular study, however, observer error is likely to remain constant. Furthermore, individual variations in gall bladder configuration would cause a systematic error in the computation of gall bladder volume so that ultrasound enables valid conclusions to be drawn concerning gall bladder dynamics in any given subject.

In the present study the overall patterns of gall bladder emptying were qualitatively similar in both healthy controls and gall stone patients. Our finding of a 'cephalic phase' of gall bladder emptying has also been reported by others..$^{20-22}$ It is generally thought that the main stimulus to gall bladder contraction is an increase in circulating cholecystokinin in response to food (although Ivy and Oldberg considered that other factors may also be important). ${ }^{23}$ The fact that gall bladder contraction occurs before the meal, and hence before a meal induced rise in plasma cholecystokinin concentration, suggests that neural rather than hormonal influences are important in the cephalic phase. Furthermore, there is still some controversy as to whether cholecystokinin acts directly on muscle cells ${ }^{24}$ or indirectly by releasing acetylcholine from cholinergic neurones. ${ }^{25}$

The initial net emptying is probably due mainly to meal stimulated cholecystokinin release but it might also be due partly to a neurally mediated extension of the cephalic phase. At first sight the early net refilling of the gall bladder was surprising, particularly as it was followed by a slower phase of net emptying to a final nadir about two hours after meal ingestion. Bile flow does increase postprandially, ${ }^{26}$ and a major factor influencing this flow is the osmotic effect of biliary bile acids. ${ }^{27-29}$ Hence an explanation for the 'early' net refilling of the gall bladder is that it occurs as a result of the mobilisation of bile acids from the intestine, with their subsequent re-uptake and secretion by the liver. This
Figure 3: Superimposed gall bladder silhouettes obtained $(A)$ from a healthy control subject and (B) from a patient with gall stones. Pre and postprandial scans are separated by the arrow. Scans were obtained at one minute intervals. 
hypothesis is supported by the results of studies by Setchell $e t a l .{ }^{30}$ They showed an increase in serum (unconjugated) bile acids which peaked between 30 and 60 minutes after a meal. In other words, the peak reabsorption of unconjugated bile acids occurred at about the same time as the early peak in gall bladder volume.

The observation that there are minute-byminute fluctuations in gall bladder volume is not new. 'Spontaneous' contractions of the gall bladder were first noted by Doyon in 1883 in curarised animals. ${ }^{31}$ Similar contractions were also noted in the dog by Bainbridge and Dale (1905), Ivy and Oldberg (1928), Crandall (1931), and Voegtlin et al (1933). ${ }^{23} 32-34$ Spontaneous rhythmic contractions of gall bladder muscle were accentuated by (a) the nerve toxin chrysotoxin, ${ }^{32}$ (b) volume distension of the gall bladder, ${ }^{31} 35$ and (c) cholecystokinin..$^{23}$ Indeed, rhythmic contractions seem to be an intrinsic property of the muscle itself and can be seen in isolated gall bladder muscle strips. ${ }^{36-38}$. More recently, Takahashi et $a l^{39}$ implanted strain gauges into the gall bladder wall of conscious dogs and observed periodic contractions of the gall bladder both in the interdigestive state (in relation to the migrating motor complex) and also postprandially. We believe that this paper is the first to describe periodic minute-by-minute gall bladder filling and emptying in humans.

Our data suggest that under physiological conditions the gall bladder handles most of the hepatic bile secreted by the liver before it is delivered into the duodenum. Previous estimates of the percentage of hepatic bile partitioned into the gall bladder vary from $35-50 \%$ in the baboon $^{40}$ and up to $75 \%$ in humans. ${ }^{+1}$ Lanzini et $a l$, however, suggest that the percentage may be as high as $80 \%$ or more. ${ }^{18}$ The human liver produces at least $1000 \mathrm{ml}$ of bile per day but although common bile duct flow rates are low during fasting $(0.5$ to $1.0 \mathrm{ml} / \mathrm{min})$, they increase after a meal to between 2 and $3 \mathrm{ml} / \mathrm{min},{ }^{26}$ which is in agreement with our estimate of approximately $1 \mathrm{ml} / \mathrm{min}$. This large flux through the gall bladder (which may be many times the fasting volume per hour) raises the question of how the gall bladder manages to concentrate bile. Although the absorptive capacity of the human gall bladder is not known, Svanvik et $a l^{42}$ estimated that in conscious monkeys the daytime absorption rate of water is approximately one third of the fasting gall bladder volume per hour. Nevertheless, it is known that bile becomes stratified in the gall bladder, with the most concentrated viscous bile lying deep within the fundus. ${ }^{43-46}$

How might the gall bladder handle such a large volume and concentrate bile at the same time? One possible explanation is that fresh hepatic bile is not freely miscible with gall bladder bile and that the rate of turnover of bile in the gall bladder varies - the 'washout model' of gall bladder emptying. In this model the highest turnover of bile would be in the neck and infundibulum with much slower rates of turnover in the fundus, thus permitting concentration of bile in the deeper 'unstirred' layers of the fundus. In this way fresh hepatic bile would enter the infundibulum and become enriched through contact with more concentrated bile. As the gall bladder contracted the deeper, more concentrated layers of bile would be exposed to the washout effect of fresh hepatic bile entering the gall bladder. This would ensure a relatively constant postprandial output of bile in response to a meal.

This study was supported in part by grants from Gipharmex SpA, Milan and by the Special Trustees of Guy's Hospital. We thank M L Usiskin, Guy's Hospital Dental School, for use of the digitise for calculating gall bladder volume.

1 Lamorte WW, Shoetz DJ Jr, Birkett DH, Williams LF Jr. The role of the gallbladder in the pathogenesis of cholestero gallstones. Gastroenterology 1979; 77: 580-92.

2 Braverman DZ, Johnson ML, Kern F Jr. Effects of pregnancy and contraceptive steroids on gallbladder function. $N \mathrm{Engl}$ f Med 1980; 302: 362-4

3 Everson GE, McKinley C, Lawson M, Johnson M, Kern F. Gallbladder function in the human female: effect of the ovulatory cycle, pregnancy, and contraceptive steroids. Gastroenterology 1982; 82: 711-9.

4 Shaffer EA, Taylor PJ, Gadomski S, Corenblum B. The effect of progestin on gallbladder function in young women. Am $\mathcal{F}$ Obstet Gynecol 1984; 148: 504-7.

5 Holzbach RT. Gallbladder stasis: consequence of long-term parenteral hyperalimentation and risk factor for cholelithiasis. Gastroenterology 1983; 84: 1055-8.

6 Roslyn JJ, Pitt HA, Mann LL, Ament ME, DenBesten L. Gallbladder disease in patients on long-term parenteral nutrition. Gastroenterology 1983; 84: 148-54.

7 Doty JE, Pitt HA, Kuchenbecker SL, DenBesten L. Impaired gallbladder emptying before gallstone formation in the prairie dog. Gastroenterology 1983; 85: 168-74.

8 Fridhandler TM, Davison JS, Shaffer EA. Defective gallbladder contractility in the ground squirrel and prairie dog during the early stages of cholesterol gallstone formation Gastroenterology 1983; 85: 830-6.

9 Pellegrini CA, Ryan T, Broderick W, Way LW, Gallbladder filling and emptying during cholesterol gallstone formation in the prairie dog. A cholescintigraphic study. Gastroenterology 1986; 90 : 143-9.

10 Maudgal DP, Kupfer RM, Zentler-Munro PL, Northfield TC. Postprandial gallbladder emptying in patients with gallstones. BMF 1980; 280: 141-3.

11 Pomeranz IS, Shaffer EA. Abnormal gallbladder emptying in a subgroup of patients with gallstones. Gastroenterology 1985 88: 787-91.

12 Krishnamurthy GT, Bobba VR, Kingston E, Turner F. Measurement of gallbladder emptying sequentially using a single dose of ${ }^{9 m} \mathrm{Tc}$-labelled hepatobiliary agent. Gastroenterology 1982; 83: 773-6.

13 Bobba VR, Krishnamurthy GT, Kingston E, Turner FE Brown PH, Langrell $\mathrm{K}$. Gallbladder dynamics induced by a fatty meal in normal subjects and in patients with gallstones: concise communication. F Nucl Med 1984; 25: $21-4$.

14 Forgacs IC, Maisey MN, Murphy GM, Dowling RH. Influence of gallstones and ursodeoxycholic acid therapy on gallof gallstones and ursodeoxycholic acid therapy on
bladder emptying. Gastroenterology 1984; 87: 299-307.

15 Fisher RS, Stelzer F, Rock E, Malmud LS. Abnormal gallbladder emptying in patients with gallstones. Dig Dis $\mathrm{Sc}$ 1982; 27 : 1019-24.

16 Jazrawi RP, Lanzini A, Britten A, Meller ST, Northfield TC Dynamics of gallbladder function and of the enterohepatic circulation studied by gamma labelled bile acid. Clin Sci 1984; 66: 10P.

17 Howard P, Murphy G, Dowling RH. Gallbladder (GB) filling and emptying in response to a meal before and during chenodeoxycholic acid (CDCA) treatment. Clin Sci 1985, 69: $9 \mathrm{P}$.

18 Lanzini A, Jazrawi RP, Northfield TC. Simultaneous quantitative measurements of absolute gallbladder storage and emptying during fasting and eating in humans. Gastroemptying during fasting and

19 Everson GT, Braverman DZ, Johnson ML, Kern F Jr. A critical evaluation of real-time ultrasonography for the study
cing of the gallbladder volume and function. Gastroenterology 1980; 79: 40-6.

20 Hansen WR, Maurer H, Haberland H. The effect of shamfeeding on gallbladder volume and circulation of bile acids. Hepatogastroenterology 1982; 29: 108-10.

21 Fisher RS, Rock E, Malmud LS. Gallbladder emptying in response to sham feeding in humans. Gastroenterology 1986 90: 1854-7.

22 Anagnostides AA, Chadwick VS, Fitzpatrick ML, Maton PN. A cephalic phase of biliary secretion. Clin Sci 1983; 65: 1-12.

23 Ivy AC, Oldberg E. A hormone mechanism for gallbladder contraction and evacuation. Am $\mathcal{F}$ Physiol 1928; 86: 599-613.

24 Severi C, Grider JR, Makhlouf GM. Functional gradients in muscle cells isolated from gallbladder, cystic duct, and
mutional muscle cells isolated from gallbladder, cystic duct, and
common bile duct. Am $\mathcal{A}$ Physiol (Gastrointest Liver Physiol) common bile duct.

25 Strah KM, Pappas TN, Melendez RL, Debas HT. Contrasting cholinergic dependence of pancreatic and gallbladder responses to cholecystokinin. Am $\mathcal{F}$ Physiol 1986; 250 G665-9

26 Hogan WJ, Dodds WJ, Geenan JE. The biliary tract. In Christensen J. A guide to gastrointestinal motility. Bristol: Wright. 1983: 157-97. 
27 Wheeler HO. Secretion of bile acids by the liver and their role in the formation of hepatic bile. Arch Intern Med 1972; 130: in the form 53 .

28 Boyer JL, Bloomer JR. Canalicular bile secretion in man. Studies utilizing the biliary clearance of (14C) mannitol. f Clin Invest 1974; 54: 773-81.

29 Guranz D, Hofmann AF. Influence of bile acid structure on bile flow and biliary lipid secretion in the hamster. Am F Physiol 1984; 247: G736-48.

30 Setchell KDR, Lawson AM, Blackstock EJ, Murphy GM Diurnal changes in serum unconjugated bile acids in normal man. Gut 1982; 23: 637-42.

31 Okada S. On the contractile movement of the gallbladder. 7 Physiol 1915-16; 50: 42-6.

32 Bainbridge FA, Dale $\mathrm{HH}$. The contractile mechanism of the gallbladder and its extrinsic nervous control. F Physiol 1905; 33: 136-55.

33 Crandall LA Jr. Mechanisms of the contraction and evacuation of the gallbladder. Arch Intern Med 1931; 48: 1217-24.

34 Voegtlin WL, McEwen EW, Ivy AC. On the humoral agents concerned in the causation of gallbladder contraction. Am F Physiol 1933; 103: 121-30.

35 Higgins GM, Mann FC. Observations on the emptying of the gallbladder. Am $\mathcal{f}$ Physiol 1926; 78: 339-48.

36 Ravdin IS, Morrison JL. Gall bladder function. I. The contractile function of the gallbladder. Arch Surg 1931; 22: 810-28.

37 Cameron AJ, Phillips SF, Summerskill WHJ. Effect of cholecystokinin, gastrin, secetin, and glucagon on human gallbladder muscle in vitro. Proc Soc Exp Biol Med 1969; 131: 149-54.

38 Mack AJ, Todd JK. A study of human gallbladder muscle in vitro. Gut 1968; 9: 546-9.

39 Takahashi I, Nakaya $M$, Suzuky T, Itoh Z. Postprandial changes in contractile activity and bile concentration in the gallbladder of the dog. Am f Physiol 1982; 243: G365-71.

40 O'Brien JJ, Shaffer EA, Williams LF Jr, Small DM, Lynn J, Wittenberg J. A physiological model to study gallbladder function in primates. Gastroenterology $1974 ; 67: 119-25$.

41 Shaffer EA, McOrmond P, Duggan H. Quantitative cholescintigraphy: assessment of gallbladder filling and emptying and duodenogastric reflux. Gastroenterology 1980; 79: 899-906.

42 Svanvik J, Allen B, Way L. Net water transport in the gallbladder of the conscious monkey. Gastroenterology 1979; gallblad

43 Tera H. Stratification of human bile in vivo. Acta Chir Scand 1960; 256 (suppl): $1-85$.

44 Nakayama F, van der Linden W. Stratification of bile in gallbladder and gallstone formation. Surg Gynecol Obstet 1975; 141: 587-90.

45 Campbell BA, Burton AC. Stratification of bile in the gallbladder and cholelithiasis. Surg Gynecol Obstet 1949; 88: 731-8.

46 Kaufman SA. Stratification (layering) of bile in the normal gallbladder. Am F Dig Dis 1959; 4: 634-7. 